Amir I. Aliyev', Gulnaz A. Rzayeva ${ }^{2}$

DOI: 10.25045/jpis.v09.i1.04

${ }^{1,2}$ Baku State University, Baku, Azerbaijan

19al.amir.ib@mail.ru, ${ }^{2}$ gulnazrzayeva@mail.ru

\title{
COMPARATIVE ANALYSIS OF INTERNATIONAL AND NATIONAL LEGAL REGULATION OF INFORMATION SPHERE
}

The article is devoted to the problems related to development and systematization of information legislation of the Republic of Azerbaijan. In this regard, international norms, complex laws and bylaws are analyzed. The authors conclude that there are different collisions in the information regulations. These collisions are analyzed in depth, and adjustment of national norms to the international standards and adoption of the unique Information Code of the Republic are recommended for the problem solution.

Keywords: information legislation, international norms, freedom of information, freedom of expression, by-laws, systematization, information code.

\section{Introduction}

First of all, it should be noted that the basic human rights and freedoms are stated in many international declarations, and states are guided by the provisions of these declarations in their national legislations. In 1946, the United Nations General Assembly declared the freedom of information as one of the basic human rights, which incorporates criteria for all freedoms protected by the UN [1]. Subsequently, the Universal Declaration of Human Rights (1948) established the freedom of information. Article 19 of the Declaration states: "Everyone has the right to freedom of opinion and expression; this right includes freedom to hold opinions without interference and to seek, receive and impart information and ideas through any media and regardless of frontiers."[2].

The abovementioned provision was further amended and proclaimed by the international norms (Article 19 of the 1966 Covenant on Civil and Political Rights [3], Article 10 of the 1950 European Convention for the Protection of Human Rights and Fundamental Freedoms [4]) in details

According to the analysis of foreign legislations, we can conclude that all states established information rights in accordance with international law. In the Constitution of the Republic of Azerbaijan (CRA), information rights are not limited to just one article covering several norms [5]. Thus, Article 50 of the Constitution, which provides for freedom of information, is considered to be the norm of basic information right. Simultaneously, many constitutional norms representing human rights and freedoms "supplement" the realization of this freedom. For example, freedom of information sets out that everyone is free to look for search, acquire, transfer, prepare and distribute information. Everyone is free to carry out creative activity. The state guarantees freedom in literary-artistic, scientific-technical and other kinds of creative activity (Article 51 of the CRA). Another example, everyone may enjoy freedom of thought and speech (Article 47 of the CRA). These types of supplementary norms constitute a multitude of normative legal acts, and for their application with the basic norms in practice, numerous legal acts are adopted. For example, the Law of the Republic of Azerbaijan "On Access to Information" dated September 30, 2005 [AR] [6] was established based on Article 50 of the CRA. It is no coincidence that the purpose of the Article 1 of this Law is to establish the legal framework for ensuring free, unrestricted and equal information access as prescribed by Article 50 of the Constitution of the Republic of Azerbaijan based on open society and democratic law-governed state principles, as well as to create conditions for control by citizens on the exercising of public duties.

In addition, the Law of AR dated March 12, 2002 "On the disclosure of information on environment" adopted on the basis of the right to acquire information on the environment condition in a constitutional order [7], the Law of AR dated 7 December 1999 on "Mass media" sets out the right 
to freedom of mass information and regulates the emerged relations [8], and the Law of AR dated June 19, 1998 on Freedom of Information [9] and others similar legislative acts are also available.

The constitutional norms and legislative acts listed in the article are mutually analyzed and comparable with international norms. The problems existing in national legislation are revealed and respective suggestions and recommendations are put forward for their solution.

\section{Freedom of information or freedom of data: analysis of legislative acts on freedom of access to information}

Freedom of information is explained by several expressions as "right to information", "freedom of information", "right to access to information" and so forth. Some authors refer freedom of information to the informatization processes [10], while others focus on the problem from the point of purely new technologies [11]. However, many researchers review this freedom of expression together with other related rights (intellectual property rights, creative freedom, etc.) $[12,13]$

As mentioned, the legislation of the Republic of Azerbaijan (AR Law "On Access to Information") sets out freedom of information (in a constitutional order) and freedom of access to information [6]. The main point, in a broader context, freedom of information provides the freedom to seek, obtain, transmit, prepare, and disseminate information. The freedom of access to information is related to only obtaining information. Consequently, the second concept is a composite element of the freedom of information specified in the Constitution [5]. We can even argue that freedom of access to information is not limited to the "Law on Access to Information". On the one hand, various normative legal acts provide for the freedom of access to information in various fields, on the other, access to information is realized not only by providing information but also by other ways.

International norms for freedom of information envisage this freedom along with other laws related to information, rather than a separate article. According to Article 19 of the Covenant on Civil and Political Rights, everyone shall have the right to hold opinions without interference; this right shall include freedom to seek, receive and impart information and ideas of all kinds, regardless of frontiers, either orally, in writing or in print, in the form of art, or through any other media of his choice. The exercise of the rights provided for in this paragraph carries with it special duties and responsibilities. In accordance with the paragraph 3 of the article, it may therefore be subject to certain restrictions, but these shall only be such as are provided by law and are necessary:

(a) For respect of the rights or reputations of others;

(b) For the protection of national security or of public order (order public), or of public health or morals [14].

The 1950 European Convention sets out the freedom of expression in Article 10, taking into account the 1948 Universal Declaration: Everyone has the right to freedom of expression. This right shall include freedom to hold opinions and to receive and impart information and ideas without interference by public authority and regardless of frontiers. This Article shall not prevent States from requiring the licensing of broadcasting, television or cinema enterprises. The exercise of these freedoms, since it carries with it duties and responsibilities, may be subject to such formalities, conditions, restrictions or penalties as are prescribed by law and are necessary in a democratic society, in the interests of national security, territorial integrity or public safety, for the prevention of disorder or crime, for the protection of health or morals, for the protection of the reputation or rights of others, for preventing the disclosure of information received in confidence, or for maintaining the authority and impartiality of the judiciary [15].

The aforementioned arguments show that in a broad aspect, freedom of information declared by constitution combines many rights and freedoms related to information. However, the question arises: If the freedom of information has a broader concept, how should the acquisition of information through survey be called? - From the point of view of the Law, it is called "Freedom of Information". However, considering the possibility of accessing information in other ways, the 
legislative concept cannot be considered successful. In our view, all these contradictions arise from the fact that the legislature differently explains the notions of "information" and "data".

Article 2 of the Law of AR "On Information, Informatization and Protection of Information" [16] and Article 3 of the Law of AR "On Access to Information" [6] also provide the same definition:

"Information - any facts, opinions, knowledge, news or other sort of information produced or acquired in result of any activities, irrespective of the date of producing, presentation form and classification " [16].

According to Article 1 of the Law of AR "On freedom of information", information means news about events, processes, facts and persons appearing in the nature, society and state regardless of the presentation form. As it is seen, the notion of information is understood as news acquired from media. What is mass media then? - In accordance with the Law of AR About Mass Media, mass media includes periodic printing editions, teleradio programs, news agencies, the Internet, information resource, the program of newsreel and other forms of distribution [8]. Thus, the information disseminated by these means is recognized as news and regulated by the Law on Freedom of Information.

From the analysis of the above-mentioned laws, it is obvious that legislation differentiates between "information" and "data". The problem is that the notion of information is wider and may comprise news. At the same time, the Law About Mass Media defines the notion of "mass information" [8]. In this case, the definition of the concept of "data" in the Law on Freedom of Information leads to repetition [9]. In our opinion, the concept of "information" specified in abovementioned laws is more comprehensive. Therefore, the terms "information" and "mass information" are sufficient, and there is no need for the definition of "data".

Another interesting aspect of the legislator's definition, in terms of information is that the facts and information here are identifiable, i.e., the facts, opinions, information, news or other characteristic statistics are referred to information. Some authors believe that such identification

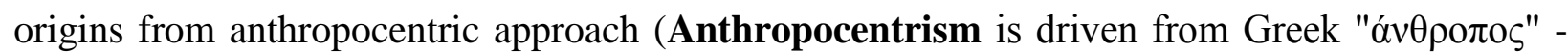
"man" and Latin, "centrum" - "center", means idealist views that regard humanity as the central element of the universe and the objective of all events in the world). This approach is not believed to meet the requirements of modern society, where ICT is widely used. Because, first, the interpretation of information just as data does not highlight information processes occurring in computer programs, computer networks, and artificial intelligence systems. Second, the genetic information of living beings is impossible to be explained within the limits of the anthropocentric approach. Therefore, in modern times, the concept of information should be explained from a different aspect. This should include information generated not only among people, but also between man and machine and among the machines [17]. In our view, there is no need to deepen this issue. Since the legislative information accepts as a result of any activity. The application of ICT and the use of computers are carried out by human being, that is, any activity is carried out and information is obtained as a result of that activity.

Legislative recognition of information shapes a new institution within the framework of information law. Since, in modern times, in legislative acts, the concept of information is represented in various forms, including "information", "mass information", "information resources", "document", "biometric information", "environmental information", "open information", "confidential information", "state secrets", "banking secrets", "personal data" and so forth. Thus, in legal literature, many authors particularly emphasize a new category of information right as "organizational form of information". They believe that, in this case, the legal information itself is systematic with its content comprising various categories [18]. We believe that all the listed terms and their legal regulation norms shape the legal institution of "legal regime or regulation of information". 
Thus, "obtaining legislative information" means the acquisition of recorded and documented information. This is proved by the provisions related to the information requests once more. Perhaps, for this reason, although the Law of AR on Access to Information has been adopted, the Law of AR on Freedom of Information has not yet been abolished. It is also proved by the fact that Article 9 of the latter defines the Law of AR "On Access to Information" as a legal basis of the terms and conditions for the acquisition of open information [6]. Consequently, the legislature, which reviews "freedom of information" from a wider aspect, links "freedom of information" with access to recorded information. It is no coincidence that Article 7 of the Law of AR "On Access to Information" deals with documented information, while Article 9 evidently indicates that this kind of information belong to information owners. (Any identifiable information with any attributes recorded on material carrier in the form of text, voice or image; irrespective of its source, place of storage, official status, type of ownership and whether or not it has been produced by the entity which it belongs to, is considered documented information). Moreover, Article 14 specifies the forms of access to information, all of which are related to documented (recorded) information. Information owner refuses the execution of the request when information owner lacks the required information or finds difficulty in determination of this information's owner as indicated in Article 21.1.2. In fact, it is possible to increase the number of such norms. In this case, contradictions occur. In our view, the main reason for the listed problems is the complex character of the information field and the lack of a single normative-legal act in this area. Furthermore, it should be noted that since the information and legal relations are newly emerged, existing normative legal acts may not fully cover the legal regulation of these relations within the country. The regulation of relationship by two different norms is also inevitable, which leads to contradictions in practice. Therefore, the interrelated issues as "information" and "data", "freedom of information" and "right to information" should be clarified. In addition, the mentioned normative legal acts should be reviewed in order to eliminate contradictions. The terms "information" and "freedom of expression" is recommended to be used as legal notions and represented in the information code.

Another issue is related to the term of "freedom of information access". Acquisition of information in many areas is envisaged in various legal acts such as freedom. However, in these cases, this freedom is realized in other ways rather than the request. Therefore, we believe that it will be even more correct, if the legislator uses the notion of "right to information" to access documented information.

\section{Interaction of freedom of information and freedom of expression: differences between international and national norms}

Freedom of information includes the acquisition, preparation, transmission and dissemination of information. Therefore, the legal aspects of freedom of thought and speech specified in Article 47 of the CRA should be interpreted in relation to freedom of information. It is no coincidence that both rules are found in the same article of the international law.

In general, freedom of thought and speech merges several interconnected and interrelated elements:

First, the freedom of each person to express their thoughts, ideas and opinions in public and to disseminate them in any legal way.

Second, provision of the right to establish and use information structures that enable freedom of thought and speech, and the freedom of the press and mass media.

Third, the freedom of access to information sources, which implies the establishment of restrictions on freedom of thought and speech by law [19].

First of all, it should be noted that the constitutional representation of freedom of thought and speech does not mean the realization of this freedom. It is impossible to define a provision mechanism unless the person disclose own views or opinions. Because, these ideas are of internal character and do not have an external form of expression. The freedom of thought and speech takes 
a form of external manifestation by being expressed, that is, transmitted and spread in different ways. This proves the close relationship between freedom of speech and freedom of information, once again. However, such a relationship may be twofold, not only one-sided, i.e. the presence of any of these rights does not depend on another. On the contrary, the lack of freedom of speech of a person who has the right to disseminate information and imposing any restrictions directly affect the dissemination of information. The most obvious example of this is a former Soviet censorship.

A person who exercises his/her freedom of thought and speech expresses his/her own convictions. Therefore, most researchers use the term "freedom of expression". Furthermore, all international documents specifying the freedom of thought and speech often use the notion of "freedom of expression". As mentioned above, freedom of thought and speech is realized through ideas and opinions. From this point of view, the use of term "freedom of expression" can be adopted. Nevertheless it cannot be identified with the concept of freedom of information. The latter is more widespread, comprising the right to access and search information. In general, freedom of expression (or freedom of thought and speech) and freedom of information can not be construed in isolation. The analysis of many decisions made by the European Court of Human Rights shows that in most cases, one of them is often of particular importance for another's execution. For example, in the case of 'Autronic Ag v Switzerland' (1990), the issue was whether the freedom of expression rights of the applicant company had been interfered with when the State regulator had refused to authorize it to receive a broadcast transmission from abroad. The Court easily found an interference with freedom of expression through the limit on the applicant's ability to receive information and ideas. Similarly, in Khurshid Mustafa and Tarzibachi v. Sweden, 2008, the Court found an interference with the right to freedom of expression based on the refusal of a landlord, upheld by the Swedish courts, to allow a tenant to install a satellite dish outside of their apartment, again on the basis that this obstructed their right to receive information.

Based on the facts, it can be concluded that freedom of information and freedom of expression is better to be grounded on international norms. Because it is impossible to imagine freedom of expression isolated from the right to access and disseminate information. Because freedom of information and freedom of thought and speech are often implemented in cooperation. They act as a condition of each other. On the other hand, given the freedom of thought and speech in the media, whether it is written or oral, the principle of freedom of media is specified in Article 50 rather than Article 47, which is not suitable [5]. From this point of view, it is more appropriate to present both freedoms under a single standard in the new edition.

\section{The evolution of information rights and freedoms in the information society of the Republic of Azerbaijan}

Guidance of human rights and freedoms in all aspects of the state policy of the Republic of Azerbaijan comes from the "higher purpose of the state" specified in the constitutional order. After the independence, Azerbaijani government focused on the elimination of existing problems in terms of creating favorable conditions for the realization of human rights and freedoms. For this purpose, specifying the rights and freedoms in the field of information in the adopted state programs and action plans is related to the acceleration of information society building in the republic. Many provisions set out in the "National Action Plan for the Protection of Human Rights in the Republic of Azerbaijan" approved by the Decree No.1880 dated December 28, 2006 of the President of the Republic of Azerbaijan and "National Action Program for improving the effectiveness of protection of human rights and freedoms in the Republic of Azerbaijan" approved by the Decree No. 1938 dated December 27, 2011 are aimed at ensuring the rights and freedoms in the field of information. For example, guided by the Decree of the President of the Republic of Azerbaijan "On some measures taken in the field of electronic services rendered by the state bodies", it was prepared the legal base in the field of rendering by state structures to the population of the electronic services corresponding to the international standards, was underlined that for 
maintenance of modern and flexible management, to raise transparency in activity of state structures and elimination of the phenomena creating conditions for corruption, it is necessary rendering electronic services to the population. To this end, an electronic service department should be established on the official websites of the central enforcement authorities, a list of documents required for the implementation of the service should be uploaded, and citizens should be provided with an electronic application of these documents. The Decree of the Cabinet of Ministers of the Republic of Azerbaijan dated November 24, 2011 on "Provision of Electronic Services in concrete spheres rendered by central enforcement authorities" and "List of Electronic Services" have been approved to ensure execution of this decree. Issues related to the implementation of e-services by state bodies are regulated by abovementioned Rules, and the "List of Electronic Services" precisely specifies the list of electronic services provided by each government agency. The e-government portal has already been developed incorporating a number of state agencies. Measures are being taken to ensure that all public service providers join the portal." [21]

Moreover, education, scientific-analytical and awareness-raising activities in the field of human rights also include the development of e-citizenship elements. These measures aim at increasing information literacy on the one hand, and at realizing information rights within new terms on the other. For example, organizing training on freedom of thought and speech for mass media, implementing awareness-raising activities on explanation of the Law of AR "On Access to Information", efficient provision of information access, and so forth.

One of the advantages of the Action Program is that the measures envisaged here to protect the rights of different groups of people, which are estimated to eliminate existing digital divide.

The Action Plan specifies the execution of the Action Plan in the further years. Incidentally, the National Action Plan in Azerbaijan was deemed to be the "best practice" by the former Commissioner for Human Rights, Thomas Hammarberg in his reports and speeches [22].

In addition, and open government-building in the Republic of Azerbaijan and the tendencies aimed at increasing transparency are of great importance for the provision of rights in the field of information. Therefore, when commenting on the current state of rights and freedoms in the field of information, it is appropriate to consider the provisions of the "National Strategy on Increasing Transparency and Fighting Corruption" approved by the Decree No. 2292 of 28 July 2007 of the President of the Republic of Azerbaijan. The strategy states that "When transparency is ensured, the public is more aware of decisions to be taken by the state authorities, there are opportunities for public discussions, there is trust in state authorities, and there is increased accountability and responsibility of state authorities. Transparency contributes to the improvement of the functioning of state authorities, more effective analysis and assessment of the functioning of state authorities." [23]

The National Strategy assesses the use of freedom of information as one of the conditions for ensuring transparency in the activities of state and local self-governance bodies. Therefore, "ensuring freedom of information" is emphasized as one of the main principles of increasing transparency and fighting corruption. According to this principle, public authorities should notify the public about their activities, except for the information restricted by law. State bodies shall take the necessary measures to ensure persons, mass media and civil society institutions to access information about their activities.

National Strategy particularly emphasizes the public monitoring and civil society issues, which is also noteworthy: "Public monitoring of the implementation of the National Strategy is provided through increasing of transparency, co-operation with civil society institutions and public awareness. In order to ensure effective public monitoring, a political, legal and cultural environment strengthening free access to information, freedom of speech and protection of human rights will be promoted. "[23] 
The Action Plan for the implementation of the Strategy for 2007-2011 envisages increasing efficiency in the application of legislation providing rights in the field of information, the opportunities of citizens to be informed about the activities of state and local self-government bodies, and the preparation of proposals on the activities of the authorized information institution.

Thus, as a result of the development of ICT, "traditional citizen" becomes an "electronic citizen" and acts as a member of information society using ICT and taking advantage of electronic (digital) opportunities. This opens up extensive opportunities for the realization of rights and freedoms in the field of information under new conditions.

\section{Conclusion}

The abovementioned facts highlight the rapid and dynamic development of the information sphere in the Republic of Azerbaijan. However, some problems persist in the national legislation due to issues arisen from the complexity of the information field and regulation of information rights and freedoms simultaneously with different legal fields. Considering the newly emerged information relationships, including the extension of information society building in Azerbaijan, existing problems can be considered as customary. Therefore, we believe that the improvement of the legal framework of the state policy in the information field, and the regular implementation of the plan of actions will eliminate the mentioned problems as the most important factors ensuring the normal development of legal information relations in the Republic of Azerbaijan.

\section{References}

1. UN

General

Assembly.

Resolution

59

$(1)$

1946 , http://www.un.org/documents/ga/res/1/ares1.htm

2. The Universal Declaration of Human Rights, http://www.un.org/en/universal-declarationhuman-rights

3. International Covenant on Civil and Political Rights, http://www.ohchr.org/EN/ProfessionalInterest/Pages/CCPR.aspx

4. European Convention on Human Rights, http://www.echr.coe.int/pages/home.aspx?p=basictexts

5. Constitution of the Republic of Azerbaijan, http://www.president.az/azerbaijan/constitution

6. The Law of the Republic of Azerbaijan On Access to Information, http://www.eqanun.az/alpidata/framework/data/11/c_f_11142.htm

7. The Law of the Republic of Azerbaijan On the disclosure of information on environment, http://www.eco.gov.az/az/183-etraf-muhite-dair-informasiya-almaq-haqqinda-azerbaycanrespublikasinin-qanunu

8. The Law of the Republic of Azerbaijan About Mass Media 1999, http://www.eqanun.az/framework/7512

9. The Law of the Republic of Azerbaijan About Mass Media, http://www.eqanun.az/framework/3420

10. Kopylov V.A. Information Law, 2nd ed., Moscow: Yurist, 2002, 512 p.

11. Lucchi N. The Impact of Science and Technology on the Rights of the Individual, Sweden: Springer, 2016, $186 \mathrm{p}$.

12. Human Rights in the Global Information Society (Information Revolution and Global Politics). Edited by Rikke Frank Jorgensen, London: The MIT Press Cambridge, Massachusets, 2006, 323 p.

13. McKenna A. A Human Right to Participate in the Information Society, New York: Hampton Press, 2011, 262 p.

14. International Covenant on Civil and Political Rights, http://www.ohchr.org/EN/ProfessionalInterest/Pages/CCPR.aspx 
15. European Convention Human Rights, http://www.echr.coe.int/pages/home.aspx?p=basictexts

16. The Law of AR "On Information, Informatization and Protection of Information", http://www.e-qanun.gov.az/framework/3525

17. Chubukova S.G., Elkin V.D. Fundamentals of legal informatics (legal and mathematical issues of informatics), Textbook, sec ed. corrected, supplemented, $\mathrm{M}:$ Law firm "CONTRACT", 2007, 209 p.

18. Bachilo I.L. Information as an object of legal relations // Scientific and technical information, vol. 1, 1997, No. 9, pp. 17-25.

19. Aliyev A.I. International Human Rights Protection: Textbook. Baku, 2009, 484 p..

20. Mendel T. Freedom of Expression: A Guide to the Interpretation and Meaning of Article 10 of the European Convention on Human Rights. Council of Europe, 2012, 91 p.

21. National Action Program for improving the effectiveness of protection of human rights and freedoms in the Republic of Azerbaijan. "Azerbaycan" newspaper, Baku, 2011, 27 December

22. Report by Commissioner for Human Rights of the Council of Europe-Thomas Hammarberg following his visit to Azerbaijan from 1 to 5 March 2010. Strasbourg, 29 June 2010, 34 p.

23. National Strategy on Increasing Transparency and Fighting Corruption. "Azerbaycan" newspaper, Baku, 2007, July 28. 